This article is (c) Emerald Group Publishing and permission has been granted for this version to appear here (https://dspace.lib.cranfield.ac.uk/index.jsp). Emerald does not grant permission for this article to be further copied/distributed or hosted elsewhere without the express permission from Emerald Group Publishing Limited. www.emeraldinsight.com

\title{
Challenges in transforming manufacturing organisations into product-service providers
}

\begin{abstract}
Purpose - The purpose of this paper is to present challenges experienced by UK manufacturing companies undergoing a servitization journey to becoming productservice providers. This paper emphasises real life complexity and the most common and problematic challenges experienced by practitioners.
\end{abstract}

Design/methodology - The paper uses an exploratory single-case study approach based on semi-structured interviews, and archival data. Twenty-two senior managers were interviewed from the product-service provider and its two suppliers, resulting in more than 400 pages of interview data. Data were analysed through an inductive research analysis by an emergent identification of patterns.

Findings - This research identifies critical and frequent challenges experienced by UK manufacturing companies undergoing a servitization journey to becoming product-service system providers. They are condensed into five pillars which constitute the architecture of challenges in servitization. The architecture of challenges in servitization provides a full description of the strategy and operations of product-service systems.

Originality/value - This paper contributes to knowledge with a new model called "the architecture of challenges in servitization". This is the only model that explains the importance of the strategic, operational and social tests that organisations confront when adopting servitization strategies. If companies understand these challenges, they have the potential to create unique sets of values for a variety of stakeholders.

Practical implications - This research provides a framework to understand, analyse and plan the strategic transformations to more highly servitized organisational forms. Practitioners should be able to identify likely issues within their own servitization plans and be better prepared, leading to easier and less risky transformation to a servitized organisation. 
Research limitations - This is qualitative research based on a single case study. Given the nature of research design, the identified patterns cannot be used as a predictive tool. However the depth of evidence is significant and allows analytical generalisations, which could lead us to tentative propositions for future research.

Keywords: Transformation, change management, product-service systems, servitization.

Paper Type: Research Paper 


\section{Introduction}

During the last decade, UK manufacturing output has remained relatively stable, whereas manufacturing profitability has been declining. There are several explanations for the relatively low level of UK manufacturing profitability, including the emergence of alternative low cost sources of supply. These low cost sources of supply affect every developed economy, not just the UK. The OECD (2007) and Porter and Ketels (2003) reports suggest that manufacturing in developed economies needs to move up the value chain and compete on the basis of value delivered rather than on the basis of cost.

Western economies have started to compete on the basis of value delivered by shifting their market share from manufacturing to more product-service oriented systems (Wise and Baumgartner 1999; Neely, 2008). This is linked to the view that manufacturing companies are becoming more oriented to the use of the product-service offering rather than the pure product (Manzini, Vezzoli and Clark, 2001; Mont, 2001; Manzini and Vezzoli, 2003). Thereby, many manufacturers have sought growth through the increased sale of services (Wise and Baumgartner, 1999, Reinartz and Ulaga, 2008). This journey towards a tightly-coupled combination of products and services is known as servitization (Vandermerwe and Rada, 1998).

Product-based manufacturing and process-based manufacturing have proved to be relatively easy to imitate by competitors, whereas product-service systems are less easy to replicate (Dickson, 1992; Ghemawat, 1986). This has pushed many manufacturers to recognise the strategic integration of services as a source of sustainable competitive advantage and corporate profitability (Oliva and Kallenberg, 2003; Cohen et al 2006; Rosen et al, 2003; DTI 2002; Newman and Cowling, 1996; Vandermerwe and Rada, 1988; Chase and Garvin, 1989). In theory, the implementation of product-service systems (PSS) leads to higher revenues and margins, but in practice, it takes time to build corporate profitability up (Gebauer, Fleisch and Friedli, 2005, Neely, 2008). The adoption of a new product-service strategy requires investments on capacity building such as the acquisition of new peoples' skills, capabilities and technologies, etc (Reinartz and Ulaga, 2008). Therefore in the shorter term, it might be challenging for organisations to make huge revenues out of a new PSS transformation; it may only be in the longer term that a new PSS strategy delivers on its promises.

Organisations such as IBM, General Electric, Xerox, Canon and Parkersell have had a significant share of revenues and profits from services since the middle of 1990s; this is attributed to a shift from product to service perspective (Quinn, Doorley and Paquette, 1990). Oliva and Kallenberg (2003), Davies (2003) and Araujo and Spring (2006) argue that during this transformation to a combined product-service offering, organisations are likely to change their strategies, operations and value chains, technologies, people expertise and system integration capabilities. However, the transformation paths from a product-centric strategy to a combined product-service strategy are still poorly understood and remain a new and complex concept (Voss et al, 2005; Johnston, 1995; Miller, et al. 2002; Tukker, 2004). Hence, the purpose of this paper is to present challenges experienced by UK manufacturing companies undergoing a servitization journey to becoming product-service providers.

\section{Background}

\section{Servitization}

Many manufacturers offer services, but may not use services as the basis of their competitive strategy. Servitization is defined as the strategic innovation of an organisation's capabilities and processes to shift from selling products to selling an integrated product and service 
offering that delivers value in use, i.e. a Product-Service System, (Baines et al., 2007; Vandermerwe and Rada, 1988). There are various forms of servitization such as the categories that Tukker proposes (2004). They range from products with services as an 'add-on', to services with tangible goods. They tend to be delivered using customer-centric strategies in order to provide 'desired outcomes' for the customer. This customer orientation consists of two distinctive elements (Oliva \& Kallenberg, 2003). Firstly, a shift of the service offering from product-oriented services to 'user process oriented services': i.e. a shift from a focus on ensuring the proper functioning and/or customer's use of the product, to pursuing efficiency and effectiveness of the end-user's processes related to the product). Secondly, a shift of the nature of customer interaction from transaction-based to relationship-based: i.e. a shift from just selling products to selling complete solutions through long relationships. Servitization frequently occurs as a response to financial difficulties, new customer demands and strategic product differentiation (Mathieu, 2001a, Oliva and Kallenberg, 2003; Gebauer et al., 2006). It has been observed in successful cases that when organisations gain insight into their customers' needs, they are able to develop more tailored offerings (Mathieu, 2001; Malleret, 2006).

In this research, servitization is defined as the journey or transformation process whereby an organisation enables its product-service offerings. Figure 1 illustrates the servitization continuum, which focuses on the analysis of the customer-supplier interface.

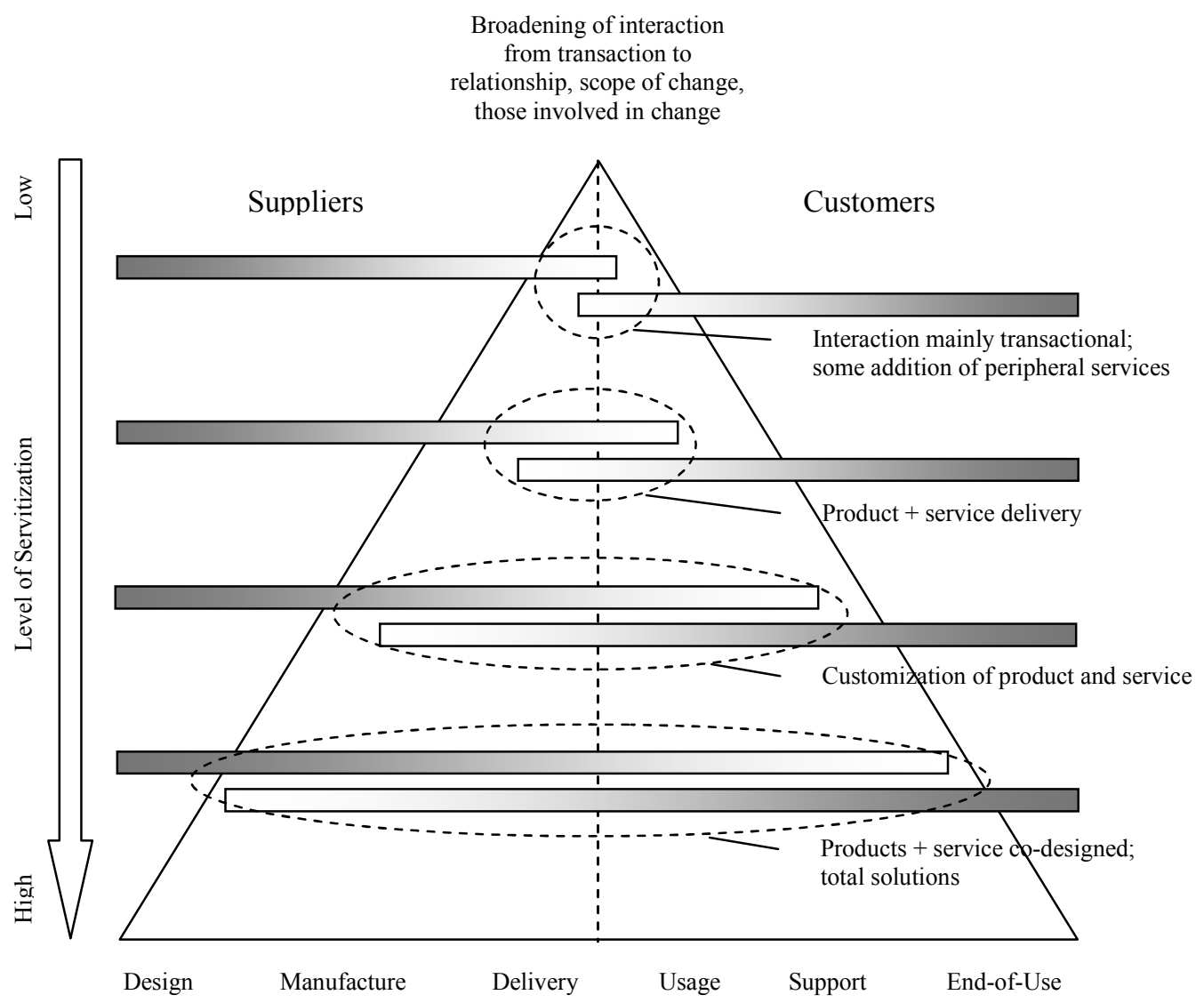

Figure 1. Servitization Continuum: a view of the customer-supplier interface 


\section{Servitization Continuum Criteria}

Four basic criteria assess an organisation's level of servitization (Table 1). They support the positioning of organisations along the servitization continuum (Figure 1). First, the "value basis of activities' assesses the value identified as the main driver to keep customers coming back to the same product-service provider (Gundlach and Murphy, 1993; Lambert, 1996, Cannon and Perreault, 1999). Second, the 'primary role of assets' gauges the nature of the asset's demand; for instance, asset utilization is focused on the delivery process of the offering rather than the tangible asset ownership (Tukker, 2004). Third, the 'offering type' shows the spectrum of product-service offering; from tangible products supported with a peripheral service to total services (Boyer, Hallowell and Roth, 2003). Finally, the 'production strategy' indicates the customization level along the servitization continuum (Gilmore and Pine II, 1997). Table I shows the criteria and their opposite poles.

Table I. Criteria for the identification of an organisation's servitization level.

\begin{tabular}{llll}
\hline Level of Servitization & High Servitization & Low Servitization & Supporting Literature \\
\hline $\begin{array}{l}\text { Value Basis of } \\
\text { Activity }\end{array}$ & Relationship based & Transactional based & $\begin{array}{l}\text { Gundlach and Murphy } \\
\text { (1993), Lambert (1996, } \\
\text { Cannon and Perreault, } \\
\text { 1999) }\end{array}$ \\
\hline $\begin{array}{l}\text { Primary Role of } \\
\text { Assets }\end{array}$ & Asset utilization & Asset ownership & Tukker (2004) \\
\hline Offering Type & $\begin{array}{l}\text { Total service } \\
\text { integration [customer } \\
\text { intimacy] }\end{array}$ & $\begin{array}{l}\text { Physical product plus } \\
\text { peripheral services } \\
\text { [Maintenance] }\end{array}$ & $\begin{array}{l}\text { Boyer K., Hallowell R. } \\
\text { and Roth A. (2003) }\end{array}$ \\
\hline Production strategy & $\begin{array}{l}\text { Pure/mass } \\
\text { customization }\end{array}$ & Mass production & $\begin{array}{l}\text { Gilmore and Pine II } \\
\text { (1997) }\end{array}$ \\
\hline
\end{tabular}

\section{Strategy and Change Management}

The strategy and change management literature suggests four schools of thought for processes of change (Pillai et al, 2007; Caldwell et al, 2005). They are:

- Planned processes: deciding upon "where we are, where we want to be and how to get there", followed by implementation and monitoring (Greenwood and Hinings, 1993).

- Emergent processes: organisations use flexibility to follow incremental changes, in adapting to unpredictable challenges (Quinn, 1989; Mintzberg and Walters, 1985; Tranfield and Smith, 1988; Hatum and Pettigrew, 2004; Lindblom and Olkkonen, 2006).

- Reactive processes: generally top-down analytical responses to abrupt stimuli (Senge, 1994; Chesley and Wenger, 1999; Weick et al.2005; Gersick, 1994; Tushman, 1997).

- Spontaneous processes: characterised by a proactive "whole system" change, which is unpredictable, uncontrolled, and continuous (Eisenhardt and Brown, 1998; Alvesson, 2004).

Each of these has relevance to the product-service transformation processes we have studied in the literature. 
While there is significant literature and theoretical models available in the general field of strategic organisational change, there are no models specific to the issues of servitization as a change process. Although the four schools of change have provided a general understanding of the strategies, processes and practices of change, they rarely lay out any specific "how-to" and certainly not any indication of the challenges that organisations undergoing servitization will face (Pawar, et al., 2009). This is not unusual in the change management literature, where generic change 'rules of thumb' are occasionally articulated, typically in the form of commentary upon the change management process and not the change itself - for example, by suggesting that organisations analyse 'where they want to be'. But advice specific to the direct act of change is more uncommon; where this literature does occur is in practitioner magazines and occasionally in specific topics. For example topics such as 'supplier development' change programmes (Rich and Hines, 1997), or implementing Performance Management Systems (Neely et al, 1997); though these are typically informed by subject knowledge rather than change management theory. These processes of change inform the nature of the challenges we have identified in transforming manufacturing organisations into product-service providers.

\section{Research Design and Methodology}

\section{Research Question}

Servitization is now widely recognized as an increasingly relevant strategy for western manufacturers to improve their competitive advantage in the market. The existing literature offers little guidance on how companies transform from being a "product-centred" organisation to being a "servitized" organisation. Change literature as we stated provides a considerable number of theoretical models, but again very little to guide and support management on how to transform, especially not in the context of servitization. Thereby, a question arises: What are the challenges confronted by organisations when transforming from being a "product-centred" to being a "servitized" organisation?

The theoretical maturity of change management literature, specifically in the context of servitization, can be regarded as nascent. Nascent theories according to Edmondson and McManus (2007:1161) are those that "received little research of formal theorizing to date or else that represent new phenomena in the world". In order to achieve a methodological fit (Yin, 2003; Edmondson and McManus, 2007) between the state of previous work, research method, analysis and expected contribution, we adopted an exploratory single case study approach (Stake, 1995). Given the theoretical immaturity of research phenomena the adoption of a single case study is appropriate as it permits for a deep research enquiry and to come as close to the research phenomena as possible (Dyer and Wilkins, 1991). Questions like "typicality", 'representativeness' or 'atypicality' of a single case are of secondary importance (Buchanan, 1999, p.77). The scope of our research is shown in Figure 2. We used two lenses of investigation in order to gain insights about the transformation of a PSS provider: We have firstly investigated (lens 1) a focal company - a PSS provider - and secondly the PSS provider's suppliers (lens 2). The reason for the adoption of the second lens was our realisation during the investigation process that some issues on the transformation path are related to suppliers' relationships, therefore the insights from the suppliers' perspective were not only desirable but necessary for better understanding of the investigated phenomena. 


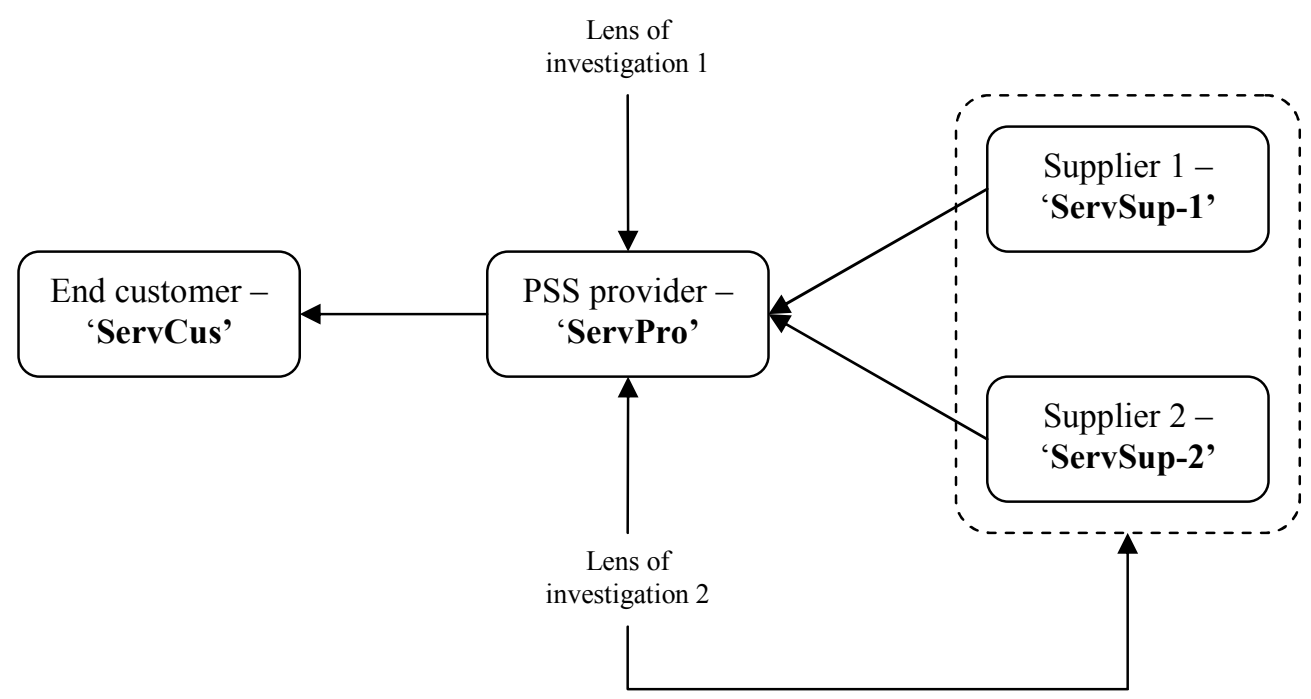

Figure 2: Scope of the research

\section{Data Collection Instrument}

The unit of analysis for the research is a transformation process from a product provider to a product-service provider within an organisation that designs, builds and delivers integrated product-service offerings. As a data collection instrument, a semi-structured interview was developed through a two-day workshop attended by researchers coming from eight different disciplines, including service marketing, strategic management, supply chain management, design engineering, manufacturing, mechanical engineering, operations strategy and innovation and change management. The use of researchers from different disciplines allowed different avenues of inquiry to be pursued in the data collection (Meredith, 1998). The semistructured questionnaire focused on determining how and why the company started the transformation to deliver product-service systems, and the challenges this was posing for the organisation. For both product-service provider and its suppliers, a series of guiding interview questions were identified, and they typically included questions like:

- Can you describe your organisation's servitization journey?

- What stage have you reached?

- Where are you going?

- What was most difficult about this servitization journey?

- What structures, processes, procedures or methods have been used to ensure coherence in organisational response to the product-service system?

\section{Selection of Case Companies}

The selection of the case companies was critical for this project, as we sought to investigate a manufacturing company who has a track record of successful provision of product related services. For this reason we have adopted a purposive sampling strategy and selected a UK based OEM that designs and manufactures high value capital equipment for the power, aerospace and defence sector. For confidentiality reasons and in order to have a greater degree of freedom in discussing our findings, we refer to the company as ServPro. ServPro operates globally and today generates over $50 \%$ of revenues from the provision of services that are closely coupled to its products. It started the transformation journey in the early $2000 \mathrm{~s}$. The company has made significant progress and is at a relatively advanced stage of servitization 
for a traditional manufacturer. This was confirmed by the HR Director who acknowledged that, "... at the interfaces between the company and the customer I think we're [now] seeing far more evidence of responsive agile service-centred behaviour". In the course of the data collection in ServPro it became clear that not only internal challenges impede the transformation process but also those external to a focal organisation. In order to get additional views on external challenges we asked respondents in ServPro to identify two or more suppliers that are of strategic importance in ServPro's provision of product-service systems. In this way we ensured that selected suppliers played an active part in ServPro's transformation process. Based on respondents' feedback two suppliers were identified for further investigation; ServSup-1, a joint-venture; and ServSup-2, a supplier from the OEM's supply network.

\section{Data Collection and Analysis}

Data were collected between June and November 2007. Interviews were firstly conducted in ServPro with key personnel from across the organisation (c.f. Design Engineering, Global Component Repair, Service Innovation/ Marketing, Projects, After-Market Services, Manufacturing Operations, Customer Services and Supply Chain). Each of the 15 interviews lasted between 2 and 3 hours and was recorded and subsequently transcribed. Interviews were then also carried out in supplying organisations. In ServSup-1 and ServSup-2 seven interviews were conducted in total with key managers (c.f. Commercial/Sales, Customer Service; Production/Operations) lasting between 1 and 2 hours each. In addition to primary data collection, the secondary data (company documentation and archival records) were collected as well, in order to achieve a theoretical triangulation (Jick, 1979; Yin, 2003). Each interview was carried out by 2 or 3 cross-discipline researchers. For instance, the customer service or production key personnel were always interviewed by representatives from "hard" (i.e. engineering, operations) and "soft" (i.e. management) disciplines.

Data were analysed through an inductive research analysis. As Cassel and Symon (1990) and Hatch (2006) highlight, this analysis is appropriate to develop theory from practice by using an interpretive epistemology. The twenty-two interviews yielded more than 400 pages of interview data. An analytical reflection of the data was carried out by the emergent identification of patterns (Cassel and Symon, 1990; Glaser and Strauss, 1967; Yin, 2003). An open coding method - a process of data disaggregation into conceptual categories - was carried out to identify patterns in the data. Codes are, according to Miles and Huberman (1994), tags or labels for assigning units of meaning to the descriptive or inferential information compiled during a study. For the purposes of coding and arranging data we used software called Mind Manager ${ }^{\mathrm{TM}}$. As a result, five categories of servitization challenges emerged as the most frequent and critical; they are discussed in the following section. For each one of the five emergent categories an explanation-building analysis was performed to understand the individual meaning of each pattern and their supporting data and quotes (Glaser and Strauss, 1967). To strengthen the reliability of the findings, the analyses were performed by the same multidisciplinary team of researchers (Yin, 2003; Miles and Huberman, 1994). After the data analysis, the findings of the research team were relayed to the interviewees in a workshop to ensure the correct representation of their views.

\section{Results}

The emergent patterns suggest five categories of challenges that a company has to consider when moving from being a product oriented organisation to a product-service oriented organisation. These challenges are:

1) Embedded product-service culture, 
2) Delivery of integrated offering,

3) Internal processes and capabilities,

4) Strategic alignment, and

5) Supplier relationships.

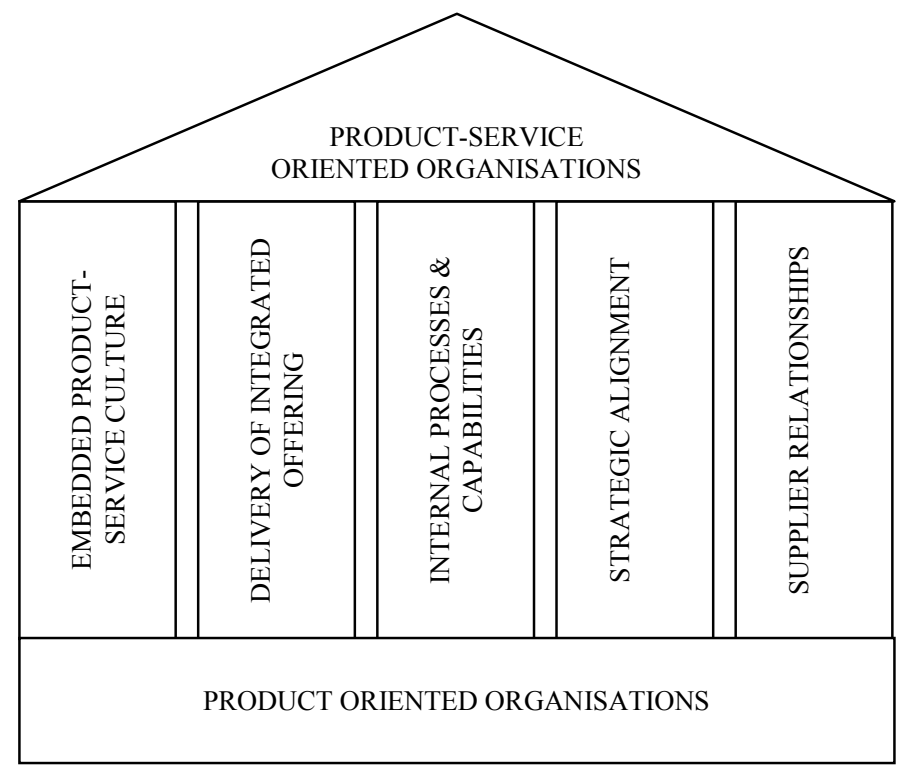

Figure 3. Architecture of Challenges in Servitization

\section{Embedded product-service culture}

Embedded product-service culture highlights the importance of the product-service culture that traditional manufacturing companies need to embrace and develop into a passion for service, in order to meet customer expectations.

Strongly embedded traditional manufacturing culture in the organisation is observed to hinder transition towards provision of an integrated offering. An interviewee said

"Culturally, people still think that at the end it's still just a big bloody product that comes in and gets overhauled." (ServPro, DS)

The cultural legacy in the company is inhibiting the transition towards a servitized strategy. The organisation needs to embrace the thinking of the end customer.

"I think it was traditional ... ponderously slow in the way that we did things, I think that the drum beat was set by the research and development programs for the major new product types. I think ... we look back as often as we look forward, everybody knows we're very old and there is an awful lot on legacy you know" (ServPro, Human Resource Manager).

"I think if this organisation is ever going to be able to integrate with our customers we've just got to talk like a customer does". (ServPro, Customer Services Manager).

Peoples' routines and the way they work differ from organisation to organisation. Provision of an integrated offering required changes in the mindsets of ServPro's employees. This has proved to be a difficult challenge. An example on speed of decision making illustrates a typical manufacturing mindset that does not match the requirements of the servitized environment. 
The interviewees highlighted that the cultural challenges described here are rooted in the move from Transaction-based to Relationship-based Value creation (see Table 1). Relationship-based value creation increases the number of staff members who interact with the customer and demands that they remain consistent with one another, which our data suggests is not an easy achievement.

\section{Delivery of integrated offering}

An integrated offering implies a greater number of customer touch-points, with the result that a broader range of personnel are being exposed to the customer than previously.

“...because ... they're [customer-facing people] doing those jobs but they can't deliver, all they can do is an acceptance, it's the rest of the company that has to deliver and if the rest of the company is still sitting believing that we're an OEM organisation that has months and years to resolve issues and respond to challenges ... then we've failed because our competitors aren't necessarily having to deal with those issues" (ServPro, HR Manager)

Introduction of new types of offering can cause issues in terms of their definition (in contracts, in negotiations, in understanding of what is required).

“...grey areas in the contract... and the need for a new mind-set to deal with this, rather than exploit the opportunity available in having unclear contracts" (ServPro, Customer Services Manager).

Misunderstandings may occur on the part of both the provider and the customer, and this may lead to an imbalance in expectations.

"...you have to accept...that they think they are paying for a certain level of service meaning they want a team of people sitting on their doorstep" (ServPro, Services Executive).

There may also be a lack of understanding about the synergies between different parts of the offering, that the whole is greater than the sum of the parts. Even to the point of reversing long held logic in negotiations.

"One of the issues that we have... customers think well if I take some of these things out of the [name of PSS offering package] offering, my price comes down, that's evident so if I can take that out, if I don't have the logistics part and take that out, I don't want that bit and that bit then surely my cost will come down but it's actually the opposite is true in my view, we may have these things like controlling of assets but actually they are the things that enable the cost to be that low, you start to take that out and the price should start going up and we need all those levers to allow us to deliver" (ServPro, Repair Engineering Manager).

There is a tendency in the organisation to revert to a focus on product, rather than the whole integrated offering (particularly when under stress).

"We are now a global company and we are going through huge growing pains, I mean absolutely enormous growing pains, we are struggling, our supply chains are struggling and focus goes on the sexy new products" (ServPro, Repair Engineering Manager).

"Normally a new service is actually adding onto an existing product design" (ServPro, Operations Centre Manager).

\section{Internal processes and capabilities}

The adoption of product-service strategy requires, among others, acquisition of new capabilities that enable the organisation to compete in new service spaces. 
Internal processes in ServPro do not enable joint design of an integrated offering. Alignment of processes that are supporting design and changes of product and service is necessary for effective provision of an integrated offering.

"Guys that do product change are not involved at all in service change, so guess why we decided service has to be aligned very much along the process and product change". (ServPro, Operations Centre Manager)

Metrics which were designed for a "product-centred" organisation require re-alignment when organisations transform towards provision of an integrated offering.

"The metrics in the individual functionalities that make up ServPro aren't really aligned... ...you don't see how that's aligned through the metric to actually deal with the integrated offering”. (ServPro, Supply Chain Manager)

"We operate too much in silos and our metrics are based on how we service one side against the other without recognition for how we are all collectively serving the end customer". (ServPro, Project Manager).

The metrics by which performance or processes are measured are becoming aligned across organisations; this is assisted by common language and knowledge sharing.

"...it does go back to a fundamental issue that ... the organisations have got everybody aligned by one set of critical measures here, we can do lots of other stuff, everybody has to be talking this language" (ServPro, Service Operations Director).

In the process of transforming towards provision of an integrated offering it has become clear that without specific infrastructure an organisation will not be able to deliver what has been promised to the end customer.

"At that point it became very clear that we did not have the infrastructure in place to provide the support we contracted". (ServPro, Customer Services Manager)

There is a lack of tools and techniques to use for the purposes of assessing the internal capabilities of organisations to design and deliver product-service offerings.

"It's the tools to assess our ability to meet a service level of agreement just as the joiner's arm is about to put pencil to a piece of paper" (ServPro, Service Operations Director)

\section{Strategic alignment}

Strategic alignment is the alignment of mindset and understanding towards service provision.

It is important that organisations share a common language and mindset, to allow a service provider to "think like a customer".

“...[PSS offering package name] world is a much better world, it's a much better aligned world with your customer because it likes everybody else, we talk the same language" (ServPro, Services Executive)

“...we [all] must learn the jargon” (ServPro, Services Innovation Manager).

There may be differences in the degree of alignment with different parts of the organisation and its customers.

"If you're in [ServPro's joint venture 1], you know when [customer A] are suffering...if you work in [internal department of ServPro] you accuse the customer, the guy across the road, there isn't that closeness, feeling the pain if you like of customers. I spent two years out in [ServPro's joint venture 1], it was one of the things that really, really hit me, it was just a 
huge alignment with the parent company, everyone knew" (ServPro, Repair Engineering Manager).

There have been situations where the organisation feels that changes to its offering are in the customers' or suppliers' best interests, but this is not recognised by the customer/supplier.

"If they want it cheap they will have to accept that what [ServPro] does is in their best interests" (ServPro, Service Operations Director).

"Those suppliers have got to hold hands with us and recognise that their route to market is through [ServProv] in a transparent sort of way" (ServPro, Service Operations Director).

There are inequities in the way customers and suppliers are treated by the organisation, but it is also recognised that there are likely to be shifts in the balance of power in these relationships in the future.

\section{Supplier relationships}

When a company is transforming to become a provider of an integrated offering, a different degree of insight into the problems and applications of customers is necessary, which calls for a greater degree of cooperation between a provider and its supporting network.

Attitudes toward suppliers have largely remained the same as they were when the organisation was still product centred.

"We would be absolutely appalled if our customers treated us the way we treat our suppliers in terms of price, costs" (ServPro, Customer Services Manager)

Even if the language in the relationship has changed, the way the suppliers are treated has in many instances remained the same.

"I think ServSup are trying to slant it a different way. I think they are tending to push full risk down onto the risk sharing partners. (ServSup-2, Customer Service Manager)

However, because of the downstream pressure on delivery of integrated offering, some changes in attitudes towards suppliers have been detected. One of the suppliers voiced that they are treated differently when it comes to support of products that are sold as an integrated offering.

"There is a lot more talk about partnership now. A lot more talk about partnering relationships when it comes to supporting their integrated offering" (ServSup-2, Commercial director)

Provision of an integrated offering requires information and know-how intensive exchange. On the upstream side ServPro is building operational linkages and knowledge-sharing routines.

"It is the data in context which is actually giving me information, giving me knowledge... The question then is well what is it that we are actually selling here? Are we doing product servitization or are we trying to go a step beyond?... In fact we have just done that with one of our customers. We get together, we present things to each other and share the insights". (ServPro, Customer Services Manager)

The information sharing between ServPro and its suppliers is much more limited compared to the downstream side. It is limited, to the extent that it produces unwanted effects not only for suppliers but potentially also for ServPro. 
"We don't receive [from ServPro] any forward planning or strategy of roles going to their market place and trying to win more business into integrated offering. We read it in the newspaper”. (ServSup-1, Customer Service Manager).

"I think the only thing I would like to see is a lot more information off ServPro to enable us to manage the risk, so they can provide us more information on their sustaining engineering bills, their modification bills." (ServSup-2, Production/Operations Director).

In spite of the supplier's willingness to adapt to a new business model and support the provision of an integrated offering, a "not invented here" type of mindset in ServPro resulted in the rejection of the supplier's help.

"We have tried to work with ServPro and we have suggested we would like to put our people on the ground of ServPro site to organise the movement of the parts from the product, through their dispatch to us to help the flow move along. Even a Kanban system, but ServPro have turned that down, so obviously they want to control their own problems" (ServSup-1, Production/Operations Director)

\section{Discussion}

This section is organised such that firstly we indicate and describe the position of individual companies on the servitization continuum. Having identified the different levels of servitization, we then continue with discussion of key transformation challenges, organised around pillars of transformation challenges (see Figure 3).

ServPro, ServSup-1 and ServSup-2 show different levels of servitization (see Figure 4).

ServPro is a high value manufacturer and provider of customer solutions. Its customers value the relationship based on the service delivered. It offers asset utilization rather than asset ownership by offering a customer intimacy service. Its production strategy is configured to provide mass customisation solutions.

ServSup-1 provides equipment that is incorporated into almost every end customer's product. Its offering is based on the delivery of physical products with few peripheral services such as maintenance. Although the value is exchanged in the transaction rather than in the relationship between supplier and provider, the supplier is customising their offering to meet particular customers' needs.

ServSup-2 offers commoditised products without existing peripheral services. Its proposed value resides on the pure transaction of the tangible offering as opposed to total service integration. Its production process is mainly ruled by a mass production strategy. 


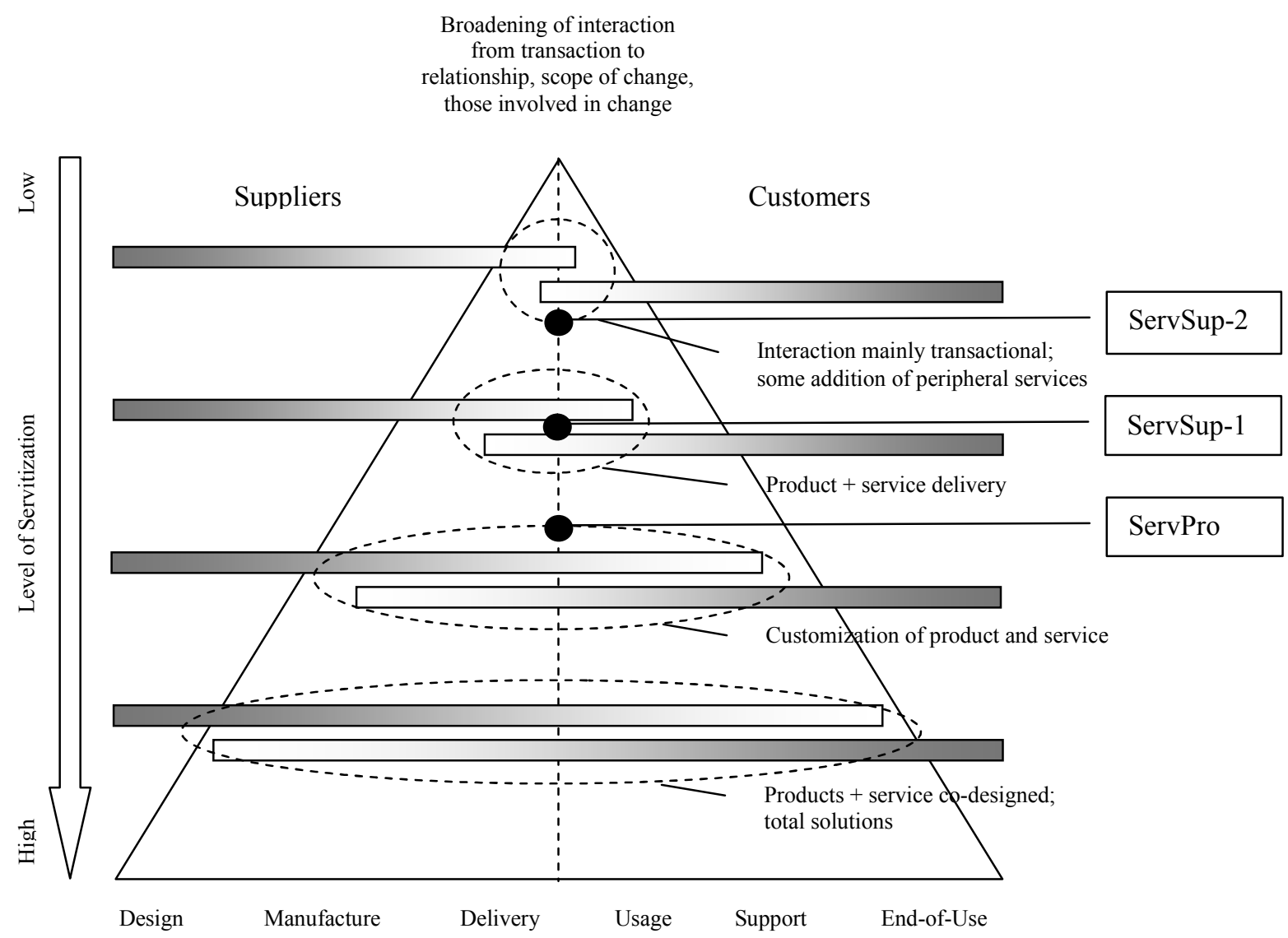

Figure 4. Positioning of case companies in the Servitization Continuum

We are indicating in this study that an organisation's journey towards higher levels of servitization (e.g. relationship-based transactions, asset utilisation, total service integration offering and high levels of production customisation), is inhibited by a variety of internal and external challenges. This research indicates that these internal and external challenges are embedded into the five categories; i.e. embedded product-service culture, delivery of integrated offering, internal processes and capabilities, strategic alignment and supplier relationships (Table II).

Table II: Key issues in each category of servitization challenges

\begin{tabular}{ll}
\hline Category & Key issues \\
\hline $\begin{array}{l}\text { Embedded product-service } \\
\text { culture }\end{array}$ & $\begin{array}{l}\text { Traditional manufacturers have strong technology orientation which inhibits } \\
\text { the transformation toward a service orientated culture. }\end{array}$ \\
\hline $\begin{array}{l}\text { Delivery of integrated } \\
\text { offering }\end{array}$ & - Product-centric orientation has to be replaced with service-centric. \\
& - Lack of organisational responsiveness can inhibit provision of integrated \\
& offering. \\
\hline $\begin{array}{l}\text { Internal processes and } \\
\text { capabilities }\end{array}$ & - Multiple touch points are required on interface between provider and customer. \\
\hline & $\begin{array}{l}\text { Alignment of product and service design processes is required for design of } \\
\text { integrated offering and effective response to customer needs. }\end{array}$ \\
\hline
\end{tabular}


- Manufacturing based metrics are not suitable for measuring product-service provision.

\begin{tabular}{ll}
\hline Strategic alignment & - Absence of internal cooperation, common language and alignment of mindsets \\
& slows down transformation efforts. \\
\hline Supplier relationships & - $\begin{array}{l}\text { Transactional relationships prevent provider's external network from } \\
\text { effectively supporting integrated offering. }\end{array}$ \\
& $\begin{array}{l}\text { Changes in the relationships between the product-service provider and its } \\
\text { customers are not reflected in the relationships with the provider's suppliers. }\end{array}$ \\
\hline
\end{tabular}

Evidence from the data is suggesting that embedded manufacturing culture, which has strong technological, product, and engineering orientation, inhibits the organisation's transformation towards becoming a servitized organisation. It seems that although ServPro's management recognised that greater customer orientation is necessary through the whole internal value chain, some parts of the organisation still did not move away from their traditional cultural roots. This is manifested for example in employees' slow response to customer needs, overengineered products, absence of understanding of customer needs and strong supervisory controls.

Because of the characteristics of service and its presence in an integrated offering, employees in the providing organisation and the end customers end up in a co-production relationship (Bowen and Ford, 2002). The degree of co-production will vary across the organisation and some functions will embrace customer orientation to a greater extent then others. There are several strategies to this. One is to build a strong service climate (Schneider, 1980) in the belief that an organisation can develop a "passion for service" on the basis of what it values, teaches, rewards and does. The other strategy is to build a service culture, as proposed by authors like Berry, $(1995 ; 1999)$ and Davidow and Uttal (1989).

In the case of ServPro, this reinforces the importance of the services culture that traditional manufacturing companies need to embrace in order to meet customer expectations. Culture helps to fill the gaps between what an organisation can train its employees to do and what the end customer expects. Bowen and Ford (2002) suggest in the context of the service industry that employees should be given a certain degree of discretion over the creation and delivery of service experience in order to satisfy differing needs and expectations of the end customer. They also argue that rigid organisational structures and strong hierarchical controls, which are so valued in the manufacturing world and so evident in the case of ServPro, can significantly impede an employee's ability to respond to the differing expectations of different customers.

The strong hierarchies that historically existed in ServPro implied a rather regimented customer interaction that involved very limited personnel/parts of the organisation. Difficulties have been seen to arise when wider parts of the organisation than before are exposed to the customer. The shift from a transactional to a more relationship-based interaction means an increase in the number and type of customer touch-points (Gundlach and Murphy, 1993; Lambert, 1996; Cannon and Perreault, 1999). This helps with closing the loop of experience of the product in use back into design, (Browning et al, 2002) and of understanding the customer, but this process is still largely under development at present. Some personnel are now experiencing the possibility of finding themselves taking direct calls from customers. In order to improve the customer interaction process, ServPro introduced a number of initiatives in which members of different parts of the organisation were exposed to the customer. This could be viewed as not only a relationship management activity, but also an informal training process. Elements of organisational learning were also fostered when 
there was mobility (both inter- and intra-organisational) of personnel. Gronroos (2000) and Bowen and Ford (2002) for instance suggest that training should be a basic component of internal marketing and that employees must not only be taught about a company's products but also about the service culture of the organisation and the delivery of integrated offerings.

The data analysis highlights a particular issue arising when an organisation coming from a product-focused background transforms to provision of a more integrated offering. There may be a tendency to focus more on the product part of the offering (this is the "comfort zone" of the organisation) than the service aspects (Mathieu, 2001, Gebauer et al., 2006). This reversion to product-centricity has been mentioned as manifesting more strongly when the organisation is put under pressure. The culture of the organisation is, to varying degrees, still that of a manufacturing firm. This is of course one of the reasons why product-service systems are difficult to replicate.

One aspect of this that the data highlighted was that of timescales. Product-centric organisations (or parts of the organisation) may be accustomed to longer timescales in dealing with a problem. To become more service-centric, the organisation must be capable of responding much more rapidly to the customer (Oliva and Kallenberg, 2003). Therefore the integrated offering requires not only an effective delivery but also a timely one, and this has to be enabled by a cohesive delivery system within the organisation.

Reinartz and Ulaga (2008) argue that the adoption of product-service strategy requires, among others, acquisition of new capabilities that enable the organisation to compete in new service spaces. Evidence showed that misalignment between internal product and service design processes hindered ServPro's ability to effectively design an integrated offering or respond to changes when they were required from the customer.

Internal alignment of performance metrics will show the organisation's collective ability to deliver an integrated offering; this was frequently exposed as an important challenge. However, not only alignment is needed but also a revision of what the metrics actually measure. Metrics that were designed for measuring outputs of "product oriented" organisations are not sophisticated enough to measure an integrated offering. This particularity disabled ServPro in effectively assessing the delivery of an integrated offering to their customers, and consequently responding with corrective actions when customer needs were not met. Johnston (1994) stated that quantitative measures of outputs for measuring services are "meaningless algebraic solutions" because they can misdirect managerial attention towards efficiency improvements of what may be only a marginally important operational sub-system. Measures for measuring inputs and outputs of integrated offerings will likely require more subjective approaches (Shaw, 1990) in order to capture heterogeneity of customer expectations.

A key finding from the data is that one of the major challenges relates to the alignment of mindset and understanding between organisations (and between different internal parts of the organisation). It was often described in the interviews with ServPro that strategic alignment is eased when there is common language between provider and customer, or between different parts of the organisation. As previously mentioned, this has successfully been enabled in ServPro by: a) mobility of personnel between organisations/divisions and b) workshops or similar events involving multi-discipline personnel.

This approach could be interpreted as containing elements of spontaneous change processes, whereby change is proactively sought by introducing disruptors (e.g. staff secondments); and of a reactive process where there may be a lead from one, more servitized, part of the organisation, which then induces other parts of the organisation to react to the new 
environment. These changes have also started to bring about alignment of metrics across different organisations.

Multiple evidence from this study suggests that a manufacturer's journey towards becoming a servitized organisation is not only hindered by internal, but also by external factors. Relationships with the external network play a critical role (Windhal and Lakemond, 2006). This is because a product is often provided by one organisation and support and services by members of a broader supply network. When a company is transforming to become a provider of an integrated offering, a different degree of insight into the problems and applications of customers is necessary, which calls for a greater degree of cooperation between a provider and its supporting network. Whilst empirical data indicate changes towards a greater degree of cooperation on the downstream side of ServPro's network, this change was not effectively translated on the upstream side. The presence of a service component in an integrated offering makes the content of exchange in a relationship significantly different when compared to that for products. Services, regarded also as "invisible assets" Itami (1987) or "tacit know-how assets" by Teece (1986) are according to Helper and Levine (1982) and Zajac and Olsen (1993) more easily employed through relational rather then transactional exchange. This helps to explain the unwanted effects that ServPro and its suppliers experienced in provision of an integrated offering. A greater degree of cooperation, which is characterised by the presence of cooperative norms of behaviour, greater know-how and information exchange, relationship transparency, mutual adaptations and tighter operational linkages (Dyer and Singh, 1998; Cannon and Perreault, 1999), would likely result in improvements in ServPro's supply network responsiveness and overall support in the provision of an integrated offering.

\section{Conclusions and Future Work}

This paper has addressed the challenges faced by manufacturers adopting servitization as a new strategy for achieving competitive advantage. The research was conducted in response to a current lack of understanding of the specific issues surrounding the transition from a product-centric to a servitized organisational structure. It is important to note that the research has sought out challenges noted by the companies; the case companies are broadly successful, and talk about being successful, in their plan to more closely integrate product and service offerings. The data represents their views on challenges that they have met and are already tackling. Key findings arising from this research centre around the proposition of a new "Five Pillar" model, where the five categories: embedded product-service culture, delivery of integrated offering, internal processes and capabilities, strategic alignment, and supplier relationships, form a supporting foundation that enables the challenges of the servitization process to be met.

The greater integration of the offering itself has direct and clear implications for the organisation(s) designing and delivering that offering. In particular there is a need for greater integration between internal functions (including requests for more integrated measurement, policy deployment and language), between an organisation and the customer using the offering, and also with suppliers. Integrated activity is seen to occur during design, negotiation, planning, manufacture, service delivery, process design, and other processes. The data suggests that servitizing organisations are increasing their involvement in such activities and improving their integration as a result. Further integration requires improvement to the five pillars of embedded product-service culture, delivery of integrated offering, internal processes and capabilities, strategic alignment, and supplier relationships.

We also relate the challenges faced by an organisation to the position on the servitization continuum that it is attempting to reach. Low levels of servitization may be achieved with 
relatively minimal adoption of the criteria embodied within the five pillars; deeper levels of servitization require a much broader interaction between supplier and customer, hence the challenges faced are more severe and must be more strongly supported by the pillars.

This research is intended to be of use to both the academic and practitioner community. It is hoped that these initial findings will open a debate around the particular challenges faced by organisations undergoing servitization, and begin to build a body of theory that addresses the current gap in the literature. For practitioners, the experiences of the case study companies presented here, and the discussion of the particular challenges that may be expected when servitizing, will help to promote awareness of what the potential "roadblocks" on the transformation journey could be.

\section{Research Limitations and Future Work}

The main limitation is that this research is based on a single case study. The insights into external challenges are limited to the upstream side of the supply chain only. Insight from the downstream side would provide additional depth and perhaps yield converging conclusions on the level of inter-organisational relationships. The future research in this area would benefit from a multiple case approach as a next step, followed by a survey which would allow for statistical generalizations.

\section{Acknowledgment}

The authors would like to acknowledge the support of the EPSRC/IMRC under grant number [IMRC 154], which is supporting Product Service Systems research.

\section{References}

Alvesson M. (2004), Knowledge Work and Knowledge Intensive Firms, Oxford University Press.

Araujo L. and Spring M. (2006), "Service, product, and the institutional structure of production", Industrial Marketing Management, Vol. 35 No. 7, pp. 797-805.

Baines, T. Lightfoot, H. Evans, S. Neely, A. et. al, (2007), "State-of-the-art in product servicesystems", Proc. IMechE Part B: Journal of Engineering Manufacture, Vol. 221 No. 10, pp. 1543- 1551.

Berry, L.L. (1999), Discovering the soul of service, New York, The Free Press.

Berry, L.L. (1995), "Relationship marketing of services: Growing interest, emerging perspectives", Journal of the Academy of Marketing Science, Vol. 23 No. 4, pp. 236-245.

Bowen, J. and Ford, R.C. (2002), "Managing Service Organizations: Does Having a "Thing” Makes a Difference?, Journal of Management, Vol. 28 No. 3, pp. 447-469.

Boyer K., Hallowell R. and Roth A. (2003) "E-services: operating strategy - a case study and a method for analyzing operational benefits", Journal of Operations Management, Vol. 20 No. 2, pp. $175-188$.

Browning, T.R., Deyst, J.J. and Eppinger, S.D. (2002), "Adding Value in Product Development by Creating Information and Reducing Risk", IEEE Transactions on Engineering Management, Vol. 49 No. 4, pp. 443-458.

Buchanan, D. (1999), "The Logic of Political Action: an Experiment with the Epistemology of the Particular", British Journal of Management, Vol. 10, pp.73-88.

Caldwell, N.D., Walker, H., Harland, C. M., Knight, L., Zheng, J., and Wakeley, T. (2005), "Promoting competitive markets: the role of public procurement", Journal of Purchasing and supply management, Vol. 11 No. 5-6, pp. 242-251.

Cannon, J. P. and Perreault, W.D. (1999), "Buyer Seller Relationships in Business Markets", Journal of Marketing Research, Vol. 36 No. 4, pp. 439-460.

Cassel C. and Symon, G. (1990), Qualitative methods in organizational research, Sage Publications, London. 
Chase, R.B. and Garvin, D.A. (1989), "The service factory", Harvard Business Review, Vol. 67 No. 4, pp. 61-69.

Chesley J.A. and Wenger M.S. (1999), "Transforming an organization: Using models to foster a strategic conversation", California Management Review, Vol. 41 No. 3, pp. 54-73.

Cohen, M.A., Agrawal, N. and Agrawal, V. (2006), "Winning in the Aftermarket", Harvard Business Review, Vol. 84 No. 5, pp. 129-138.

Davidow, W.H., \& Uttal, B. (1989), Total customer service, New York, Harper \& Row.

Davis A. (2003), "Integrated solutions: the changing business of systems integration", In Andrea Prencipe, Andre Davids and Mike Hobday (Eds.); The business system integration. Oxford, Oxford University Press.

Dickson, P.R. (1992), "Toward a General Theory of Competitive Rationality", Journal of Marketing, Vol. 56 No. 1, pp. 69-83.

DTI (2002), “The Government's Manufacturing Strategy" London: Department for Trade and Industry

Dyer, J. and Singh, H. (1998), "The relational view: Cooperative strategies and sources of interorganizational competitive advantage", Academy of Management Review, Vol. 23 No. 4, pp. 660-679.

Dyer, W.G. Jr. and Wilkins, A.L. (1991), "Better Stories, Not Better Constructs, to Generate Better Theory: A Rejoinder to Eisenhardt", The Academy of Management Review, Vol. 16, No. 3, pp. 613-619.

Edmondson, A.C. and McManus, S.E. (2007), "Methodological Fit in Management Field Research", Academy of Management Review, Vol. 32, No. 4, pp. 1155-1179.

Eisenhardt, K.M. and Brown, S.L. (1998), "Time Pacing: Competing in Markets that Won't Stand Still", Harvard Business Review, Vol. 76, No. 2, pp. 59-65.

Eisenhardt, K.M. (1989), "Building Theories from the Case Study Research", Academy of Management, The Academy of Management Review, Vol. 14 No.4, pp. 532-550.

Gebauer H., Fleisch E. and Friedli T. (2005), "Overcoming the Service Paradox in Manufacturing Companies”, European Management Journal, Vol. 23 No. 1, pp. 14-26.

Gebauer H., Friedli T. and Fleisch E. (2006); "Success factors for achieving high service revenues in

manufacturing companies"; Benchmarking, Vol. 13, No. 3, pp. 374-386

Gersick, Connie J.G. (1994), "Pacing strategic change: The case of a new venture", Academy of Management Journal; Vol. 37 No. 1, pp. 9-45.

Ghemawat, P. (1986), "Sustainable Advantage", Harvard Business Review, Vol. 64 No. 5, pp. 53-58.

Greenwood, R. and Hinings, C.R. (1993), "Understanding strategic change: The contribution of archetypes", Academy of Management Journal, Vol. 36, No. 5, pp. 1052-1081.

Gilmore J. and Pine II J. (1997), "The four faces of mass-customization”, Harvard Business Review, Vol. 75 No. 1, pp. 91-101.

Glaser B. and Strauss A. (1967), The discovery of grounded theory: strategies for qualitative research, Chicago, Aldine.

Gronroos, C. (2000), Service management and marketing (2nd ed.). Chichester, England: Wiley.

Gundlach, G.T. and Murphy, P.E. (1993)," Ethical and legal foundations of relational marketing exchanges", Journal of Marketing, Vol. 57, No. 4, pp. 35-46.

Hatch M. (2006), Organisation theory, $2^{\text {nd }}$ Edition, Oxford University Press

Hatum A. and Pettigrew A. (2004), "Adaptative response under competitive pressure: organisational flexibility in an emergent economy", Management Research, Vol. 2, No. 2, pp. 97-114.

Helper, S. and Levine, D. I. (1992), "Long-term supplier relations and product-market structure", Journal of Law, Economics \& Organization. Vol. 8, No. 3, pp. 561-582.

Itami, H. (1987), Mobilizing invisible assets, Boston: Harvard University Press,

Jick, T. (1979), "Mixing qualitative and quantitative methods: triangulation in action", Administrative Science Quarterly, Vol. 24 No. 4, pp. 602-611.

Johnston, R. (1994), "Operations: From factory to service management", International Journal of Service Industry Management, Vol. 5, No.1, pp. 49-63. 
Johnston, R. (1995), "The determinants of service quality: satisfiers and dissatisfiers", International Journal of Service Industry Management, Vol. 6 No. 5, pp. 53-71.

Lambert, D.M., Emmelhainz, M.A., and Gardenr, J.T. (1996), "Developing and Implementing Supply Chain Partnerships", The International Journal of Logistics Management, Vol. 7, No. 2, pp. 117.

Lindblom A. and Olkkonen R. (2006), "Category management tactics: an analysis of the manufacturers' control”, International Journal of Retail and Distribution Management; Vol. 43, No. 6, pp. 482-496.

Malleret V. (2006), "Value creation through service offers", European Management Journal, Vol. 24, No. 1, pp. 106-116.

Manzini, E. and Vezzoli, C. A (2003), "Strategic design approach to develop sustainable product service systems: examples taken from the "environmentally friendly innovation", Journal of Cleaner Production, Vol. 11, No. 8, pp. 851-857.

Manzini, E., Vezzoli, C., and Clark, G. (2001), "Product service systems: using an existing concept as a new approach to sustainability", Journal of Design Research, Vol. 1, No. 2

Mathieu V. (2001), "Product services: from a service supporting the product to service supporting the client", Journal of Business \& Industrial Marketing, Vol. 16. No.1, pp. 39-58.

Meredith, J. (1998), "Building operations management theory through case and field research", Journal of Operations Management, Vol. 16 No. 4, pp. 441-454.

Miles, M.B. and Huberman, A.M. (1994), Qualitative Data Analysis: $2^{\text {nd }}$ Edition, Thousand Oaks, California, SAGE Publications.

Miller D. Hope Q., Eisengstat R. Foote N. and Galbraith (2002), "The problem of solutions: Balancing clients and capabilities", Business Horizons, Vol. 45 No. 2, pp. 3-12.

Mintzberg H, and Waters J. (1985), "Of strategies, deliverate and emergent”; Strategic Management Journal; 6 (3): 257-272

Mintzberg, H. (1996), "Managing Government, Governing Management”, Harvard Business Review, Vol. 74 No. 3, pp.75-83.

Mont, O.(2001), "Introducing and developing a PSS in Sweden", IIIEE, Lund University, p. 6.

Neely, A. (2008), "Exploring the financial consequences of the servitization of manufacturing"; Journal Operations Management Research, Vol. 1, No.2, pp. 103-118.

Newman K. and Cowling A. (1996), "Service quality in retail banking: the experience of two British clearing banks", International Journal of Bank Marketing, Vol. 14, No. 6, pp. 3-11.

OECD. (2007) "Staying Competitive in the Global Economy: Moving up the Value Chain", OECD Report, Paris, France.

Oliva, R. and Kallenberg, R. (2003), "Managing the transition from products to services" International Journal of Service Industry Management, Vol. 14 No. 2, pp. 160-172.

Pawar, K.S., Beltagui, A. and Riedel, J.C.K.H. (2009), "The PSO triangle: designing product, service and organisation to create value", International Journal of Operations and Production Management, Vol. 29 No. 5, pp. 468-493.

Pillai, K.G. and Hofacker C. (2007), "Calibration of Consumer Knowledge of the Web", International Journal of Research in Marketing, Vol. 24 No.3, pp. 254-267.

Porter, M. and Ketels, C. (2003), UK Competitiveness: Moving to the Next Stage, Department of Trade and Industry, London, UK.

Quinn B. J. (1989), "Strategic change: logical incrementalism", Sloan Management Review, Vol. 30 No.4, pp. 45-60.

Quinn, B., Doorley, B., and Paquette, P. (1990), "Beyond products: service-based strategies", Harvard Business Review, March-April

Reinartz W. and Ulaga W. (2008), "How to sell service more profitably", Harvard Business Review, Vol. 86, No. 5, pp. 90-96.

Rich R. and Hines P. (1997), "Supply-chain management and time-based competition: the role of the supplier association", International Journal of Physical Distribution \& Logistics Management. Vol. 27, No. 3/4, pp. $210-225$. 
Rosen, L. D., Karwan K. R. and Scribner, L.L. (2003), "Service quality measurement and the disconfirmation model: taking care in interpretation", Total Quality Management, Vol. 14, No. 1, pp. 3-14.

Schneider, B. (1980), "The service organization: Climate is crucial", Organizational Dynamics, Vol. 9, No. 2, pp. 52-65.

Senge P. (1994), The Fifth Discipline Fieldbook; Nicholas Brealey Publishing Ltd.

Shaw, J.C. (1990), The service focus: Developing winning game plans for service companies 5-23. Homewood, IL: Dow Jones-Irwin.

Stake, R. E. (1995), The Art of Case Study Research, Sage Publications, Thousand Oaks, California, USA

Teece. D. (1986), "Profiting from technological innovation: Implications for integration", Research Policy, Vol. 15 No. 6, pp. 285-305.

Tranfield D. and Smith S. (1988), "Managing rapid change", Management Decisions, Vol. 26 No. 1, pp. 53-59.

Tukker, A. (2004), "Eight Types of Product-Service System: Eight Ways to Sustainability? Experiences from SusProNet", Business Strategy and the Environment, Vol. 13, No. 4, pp. 246 260.

Tushman M. L. (1997), “Winning through innovation”, Strategy \& Leadership, Vol. 25 No. 4, pp. 1419

Vandermerwe, S. and Rada, J. (1988), "Servitization of business: Adding value by adding services", European Management Journal, Vol. 6 No. 4, pp. 314-324.

Voss C.A. (2005), "Alternative paradigms for manufacturing strategy", International Journal of Operations \& Production Management, Vol. 25 No. 2, pp. 1211-1222.

Voss, C., Tsikriktsis, N. and Frohlich, M. (2002), "Case research in operations management", International Journal of Operations and Production Management, Vol. 22 No. 2, pp. 195-219.

Weick K.E., Sutcliffe K.M. and Obstfeld, D. (2005), "Organizing and the Process of Sense making", Organization Science, Vol. 16 No. 4, pp. 409-421.

Windahl C. and Lakemond N., (2006), "Developing integrated solutions: The importance of relationships within the network", Industrial Marketing Management, Vol. 35 No. 7, pp. 806818.

Wise, R. and P. Baumgartner (1999), "Go downstream: the new profit imperative in manufacturing"; Harvard Business Review, Vol. 77 No. 5, pp. 133-141.

Yin, R.K. (2003) Case Study Research: Design and Methods, Third Edition. London: Sage Publications.

Zajac. E.I. and Olsen. C.P. (1993), "From transaction cost to transaction value analysis: Implications for the study of inter-organizational strategies, Journal of Management Studies, Vol. 30, No. 1, pp. 131-145. 